General palaeontology, systematics and evolution (Vertebrate palaeontology)

\title{
Early Late Miocene insectivores (Eulipotyphla, Mammalia) from the Cañada section (Province of Zaragoza, east Central Spain)
}

\author{
Insectivores (Eulipotyphla, Mammalia) du Miocène Supérieur de la section de la \\ Cañada (Prov. de Zaragoza, centre-est de l'Espagne)
}

\author{
Lars W. van den Hoek Ostende ${ }^{a}$, Paloma López-Guerrero ${ }^{b, *, c}$, Pablo Peláez-Campomanes ${ }^{d}$, \\ María A. Âlvarez-Sierra ${ }^{\mathrm{b}, \mathrm{c}}$, Israel García-Paredes ${ }^{\mathrm{c}}$ \\ a Netherlands Centre for Biodiversity-Naturalis, Darwinweg 2, 2333 CR Leiden, The Netherlands \\ b Departamento de Paleontología, Facultad de Ciencias Geologicas, Universidad Complutense de Madrid, C/José Antonio Novais 2, 28040 Madrid, Spain \\ c Departamento de Geología Sedimentaria y Cambio Medioambiental, Instituto de Geociencias IGEO (CSIC-UCM), C/José Antonio Novais 2, 28040 Madrid, \\ Spain \\ ${ }^{d}$ Departamento de Paleobiología, Museo Nacional de Ciencias Naturales-CSIC, C/José Gutiérrez Abascal 2, 28006 Madrid, Spain
}

Keywords:

Vallesian

Biostratigraphy

Palaeoecology

Desmanella

Postpalerinaceus

\section{Mots clés:}

Vallésien

Biostratigraphie

Paléoecologie

Desmanella

Postpalerinaceus

\section{A B S T R A C T}

Vallesian (early Late Miocene) strata from the recently introduced Cañada section(province of Zaragoza, east Central Spain) have yielded fairly large insectivore assemblages. These show that, after the generally dry Aragonian, the Vallesian gave rise to more humid conditions that were favourable to insectivores, both in number of taxa, and in overall number of specimens. The assemblage of Cañada 8 (Biozone $\mathrm{H}$ ) is dominated by shrews, whereas the assemblage of Cañada 10 (uppermost Biozone $\mathrm{H}$ ) contains the oldest record of Desmanella in the area. This seems to signify a bioevent in which after millions of years of absence, talpids return to the area. In addition to the Vallesian assemblages, a small Turolian insectivore fauna has been recovered. On the basis of the rodents, Cañada 12 was assigned to Biozone $\mathrm{L}$, and the insectivore assemblage is very similar to the assemblages from the Teruel basin of that zone. This implies that the discovery of Postpalerinaceus in Cañada 12 is the youngest published record of this large spiny hedgehog.

\section{R É S U M É}

Les niveaux Vallésiens récemment présentés de la section de la Cañada ont livré de relativement grands assemblages d'insectivores. Ces derniers attestent que les conditions climatiques, alors relativement sèches à l'Aragonien, deviennent plus humides au Vallésien, qu'un environnement favorable aux insectivores se développe, ces derniers étant, par comparaison, bien mieux représentés autant par le nombre de taxa que par l'abondance relative des spécimens présents dans les assemblages. L'assemblage Cañada 8 (Biozone $\mathrm{H}$ ) est dominé par les musaraignes, tandis que l'assemblage Cañada 10 (partie supérieur de la Biozone $\mathrm{H}$ ) contient le plus ancien Desmanella de la région. Cette découverte semble marquer un événement durant lequel, après des millions d'années d'absence, les talpidés ré-immigrent en Espagne du centre-est. En plus des assemblages vallésiens, une faunule turolienne est décrite. 


\section{Introduction}

In their overview of the results from the Working group on Insectivores from the Neogene of Eurasia (WINE), Van den Hoek Ostende et al. (2009b, fig. 4) presented a graph with the number of insectivore localities in Spain and in the rest of Europe. From the high number of Spanish localities for MN $9(n=15)$ and particularly MN $10(n=37)$, one would get the impression that the insectivores of the Iberian Vallesian are amply known. In fact, however, although the insectivores appear regularly on faunal lists, very few extensive descriptions from Vallesian insectivores exist, and most of them are outdated (Van den Hoek Ostende and Furiô, 2005; Furiô et al., 2011a).

Recently, López-Guerrero et al. (2011) introduced the Cañada section in the Calatayud-Montalbán Basin, providing a welcome addition to the Vallesian record of east Central Spain. The section near the village of Daroca encompasses a series of superimposed fossiliferous localitites (Fig. 1). Some of the sites yielded an as yet unknown combination of taxa, such as the co-occurrence of the glirid Ramys multicrestatus and the hamster Hispanomys nombrevillae (López-Guerrero et al., 2011). Overall, the Cañada section, particularly in combination with the nearby Nombrevilla section (Álvarez-Sierra et al., 2003), provided a denser record for Zones $\mathrm{H}$ and I (which correlate to MN 9), allowing us to study the faunal development of the early Vallesian in more detail. In addition, the highest levels of the Cañada section proved to be of Turolian age, correlating to Biozone L of Van Dam et al. (2001), and yielded the youngest faunas and first Turolian record of the area to date.

Despite the overall quite limited sample sizes, some of the assemblages proved to be rich in insectivores, and potentially a valuable addition to our knowledge of the group on the Iberian Peninsula. The Cañada insectivores are the subject of this article. The rodents of the section are described as part of the PhD thesis of P.L.G. A detailed study on the Cricetodon-like rodents is currently in progress (Lôpez-Guerrero et al., submitted).

\section{Material and methods}

The material was collected by screen-washing the sediment using a mesh size of $0.7 \mathrm{~mm}$. Details on the sampling and the geology of the section are given in Lôpez-Guerrero et al. (2011).

The material was measured using a Leica $16 \mathrm{Z}$ microscope with associated software. The molars were oriented before measuring according to De Jong (1988). The three measurements given for lower molars are the length, trigonid width and talonid width, respectively. The measurements given for the soricid upper molars are the buccal length and posterior width measured according to the scheme given by Reumer (1984). All measurements are in millimeters.

The material from the Cañada section is stored at the Museo Nacional de Ciencias Naturales-CSIC (Madrid, Spain).

\section{Systematic palaeontology}

\author{
MAMMALIA Linnaeus, 1758 \\ ERINACEOMORPHA Gregory, 1910 \\ ERINACEIDAE Fischer, 1814 \\ ERINACEINAE Fischer, 1814 \\ Erinaceinae indet.
}

\section{Fig. 2.1-2.3}

Material: Cañ 6: P2 sin. $(1.88 \times 1.47)$; Cañ 8 : I2 sin. $(1.49 \times 1.20)$; Cañ 10 : p3 dext. $(1.74 \times 1.66)$.

\section{Description:}

12: The outline of the occlusal surface is elliptical, the crown being somewhat longer than wide. The tip of the cusp lies anterolabially of the centre. It carries a faint, backwards directed rib. The posterolingual side of the cusp is slightly concave. The incisor has one sturdy root, which is only slightly directed backwards.

P2: The outline of the occlusal surface is sub-elliptical, with a slightly concave posterior side. The tip of the only cusp lies in the front part of the premolar. It has a faint rib on its posterolabial flange. This rib ends in a small bulge in the posterolabial corner of the P2. Only a small part of the roots has been preserved. The cross-section of the anterior root is elliptical; the cross-section of the posterior root has a more irregular shape, indicating that it may have consisted of the mergure of two roots.

p3: The occlusal surface is heart-shaped, with a nearly straight posterior side. The tip of the only cusp lies just anterolingually to the centre of the premolar. At the back, there is a small posterolabial cusplet. The premolar has one root positioned below the back of the crown and directed backwards.

\section{Remarks:}

The spiny hedgehogs are in the Vallesian assemblages of the section only represented by isolated premolars, which cannot be identified with any kind of certainty. The finds seem to be too small to be assigned to Postpalerinaceus, the large erinaceine which is regularly found in the Late Miocene of Spain. Erinaceines are found occasionally in the Middle Miocene of the nearby Aragonian type area, but these finds are also unidentified isolated dental elements.

\section{cf. Postpalerinaceus Crusafont-Pairô and Villalta, 1947}




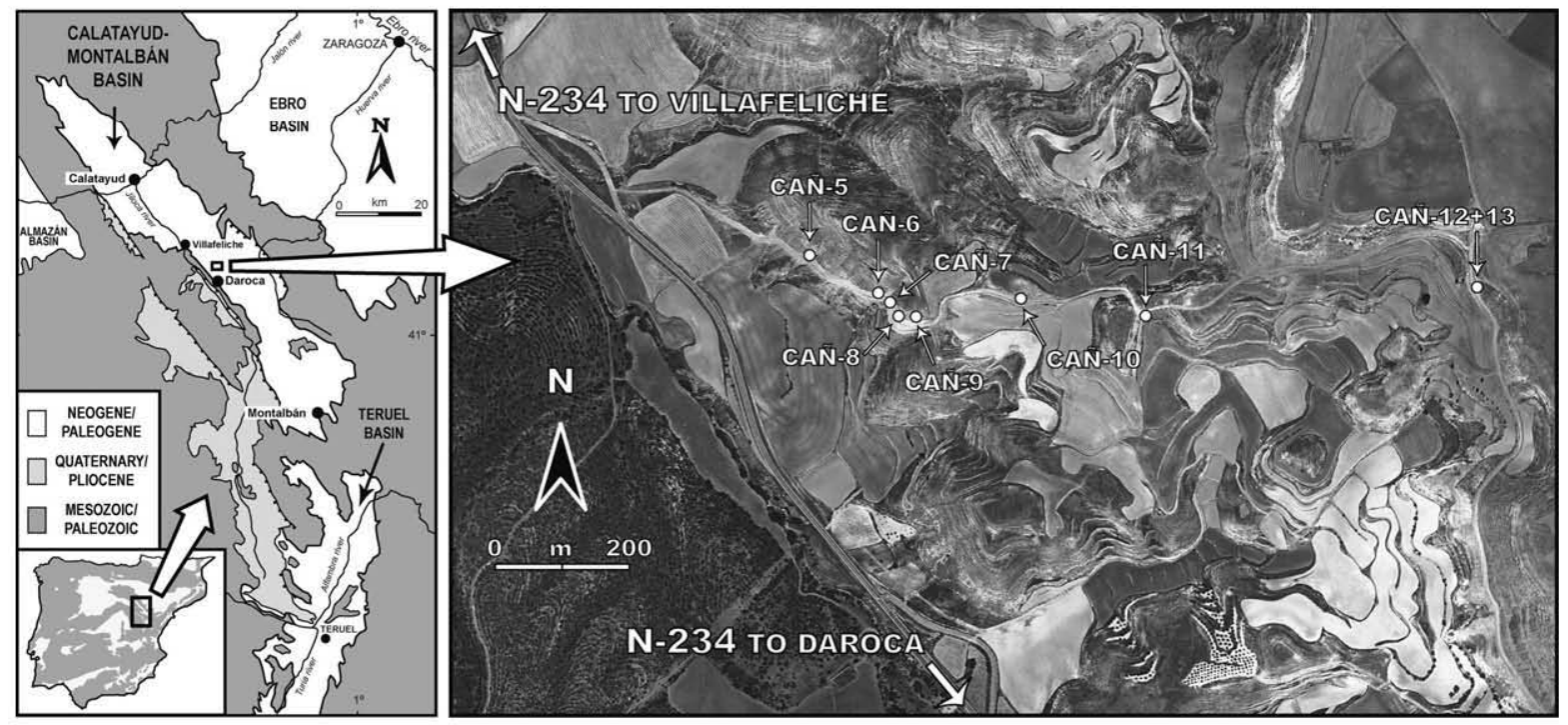

Fig. 1. Map showing the topography of the Cañada section and the position of the various localities within the section.

Fig. 1. Carte montrant la topographie de la section de la Cañada et la position des différentes localités au sein de la section.

From López-Guerrero et al., 2011.

Material: Cañ 12: P4 sin. with damaged metastyle.

\section{Description:}

The outline of the occlusal surface is subrectangular, the labial side is only somewhat wider than the lingual side. The paracone is massive, and its base reaches down to the middle of the premolar. Its posterocrista is hooked halfway. There is no parastyle, but there is a slight bulge in the outline in front of the paracone, with a very short patch of cingulum just lingually of that bulge. The protocone is about twice the size and the height of the hypocone. The latter lies posterolingually to the protocone. The two cusps are interconnected by a low ridge. The basin between the hypocone and the posterior part of the paracone slopes down to the back. It is bordered by a rather indistinct posterior cingulum.

\section{Remarks:}

The single most notable character of the Cañada 12 premolar is its very large size. It fits the size range of the large erinaceine Postpalerinaceus vireti. This species is mainly known from Vallesian localities, but within Spain, it has also been reported from the early Turolian in the Teruel Basin (Los Aguanaces, Vivero de Pinos, Biozone K; Adrover, 1986; Van Dam et al., 2001). As Cañada 12 correlated to Biozone L of Van Dam et al. (2001) (LópezGuerrero et al., 2011), the Postpalerinaceus find would be the youngest record on the Iberian Peninsula. It has, however, been reported from the youngest part of the Miocene in France (Lissieu, MN 13; Mein, 1999). A review of the Late Miocene erinaceine material would be needed to give an assessment of this genus' true stratigraphic and biogeographical range.

GALERICINAE Pomel, 1848

Galerix Pomel, 1848

cf. Galerix sp.
Fig. 2.5, 2.6

Material: Cañ 8: p3 dext. (1.66 × 1.03), Cañ 9: lingual portion of M2 dext.

\section{Description and remarks:}

Whereas most of the galericine material of the Cañada section can be comfortably assigned to Parasorex, two elements seem to be better placed in Galerix. The presence of this genus had not yet been noted in Lôpez-Guerrero et al. (2011).

A large p3 from Cañada 8 shows a very strong anterolingual cusp in front of the protoconid. The premolar is bordered by a narrow posterior shelf. The p3 falls within the size ranges of those of Galerix exilis as given by De Jong (1988), but is longer than the measurements of Parasorex p3 from Pedregueras 2A from that same publication (there as Galerix socialis). A lingual fragment of a galericine M2 dext. (Cañ 9-42) shows the presence of a protocone-metaconule connection. According to Van den Hoek Ostende (2001), this connection is invariably absent in Parasorex. Recently, Prieto et al. (2012) showed that this connection can be present as a primitive remnant in Parasorex populations, although this could be the case for the Cañada 9 specimen, but it could also very well represent one of the last surviving Galerix. In the absence of more diagnostic elements like the p4 and P3, this identification remains tentative. However, the genus is known still to be present in Carrilanga 1, where it is found next to Parasorex (De Jong, 1988). Thus, recognizing the genus in Cañada 8 and 9 would only represent a small extension of its known stratigraphic range.

Parasorex von Meyer, 1865

Parasorex sp. 


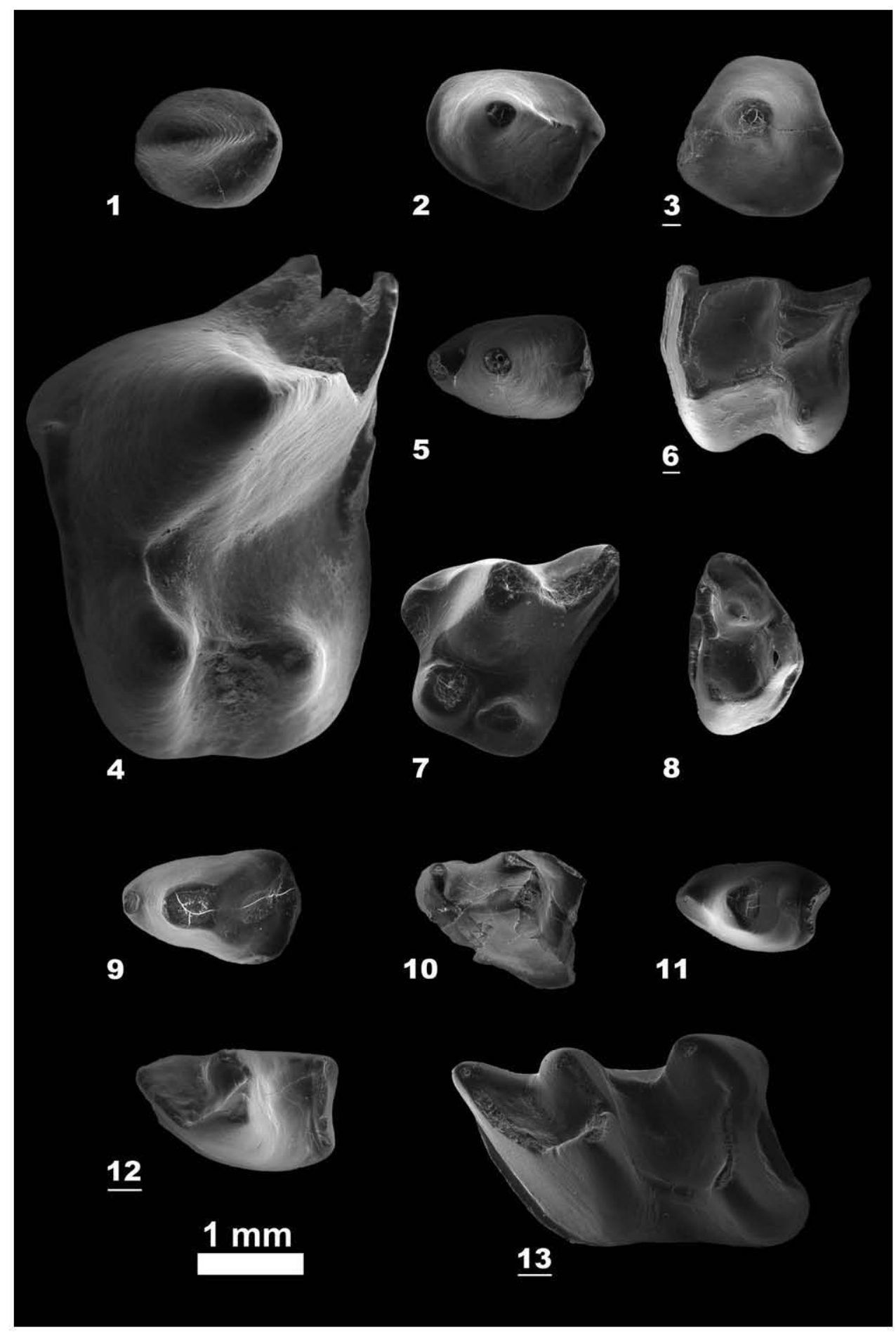

Fig. 2. Erinaceids from the Cañada section. Erinaceinae indet.: 1. I2 sin. (CAÑ 8-86); 2. P2 sin. (CAÑ 6-40); 3. p3 dext. (CAÑ 10-12). cf. Postpalerinaceus: 4. P4 sin. (CAÑ 12-100). Galerix sp.: 5. p3 sin. (CAN 8-84); 6. M2 dext. fragm. (CAN 9-42). Parasorex sp. from the Vallesian: 7. P3 dext. (CAÑ 8-100); 8. M3 sin. (CAÑ 8-112); 9. d3 sin. (CAÑ 8-111); 10. d4sin. (CAN 8-112); 11. p3 sin. (CAÑ 10-42). Parasorex sp. from the Turolian: 12. p4 dext. (CAÑ 12-94); 13. m1 dext (CAN 12-90.)

Fig. 2. Erinacéidés de la section de la Cañada. Erinaceinae indet. : 1. I2 sin. (CAÑ 8-86);2. P2 sin. (CAÑ 6-40); 3. p3 dext. (CAÑ 10-12). cf. Postpalerinaceus : 4. P4sin. (CAÑ 12-100). Galerix sp. : 5. p3 sin. (CAÑ 8-84); 6. M2 dext. fragm. (CAÑ 9-42). Parasorex sp. du Vallésien: 7. P3 dext. (CAÑ 8-100) ; 8. M3 sin. (CAÑ 8-112); 9 . d3 sin. (CAÑ 8-111); 10. d4 sin. (CAÑ 8-112); 11. p3 sin. (CAÑ 10-42). Parasorex sp. du Turolien: 12. p4dext. (CAÑ 12-94); 13. m1 dext. (CAÑ 12-90). 


\section{Fig. 2.7-2.13}

Material: Identifiable fragments of this galericine are present in almost all of the assemblages. Complete specimens, however, are much rarer in our material. These comprise of: Cañ 8: 1 P3 dext. $(2.37 \times 2.09), 1$ M3 sin. $(1.21 \times 1.84), 1 \mathrm{~d} 3 \sin .(1.77 \times 1.17) 1$ slightly damaged d4 sin. (-x-); Cañ 10: 1 p3 sin. (1.56 $\times 0.87)$; Cañ 12: 3 M3 sin. $(1.31 \times 1.92 ; 1.20 \times 1.96 ; 1.31 \times 1.97)$, 1 p4 dext. (1.91 × 1.29), $1 \mathrm{~m} 1$ dext. $(3.35 \times 1.94 \times 2.05)$.

\section{Description and remarks:}

The rather limited material shows the typical characteristics of the genus Parasorex as listed by Van den Hoek Ostende (2001). The P3 carries a hypocone, the p4 has a well-developed trigonid, and in the few fragments of M1/M2 in which this can be judged, the posterior arm of the metaconule reaches up to the posterolabial corner of the molar.

The taxonomy of Parasorex and Parasorex-like forms is currently in a state of flux (Furió et al., 2011b; Prieto et al., 2011, 2012), and the Cañada material is too scanty to contribute to these discussions.

\section{SORICOMORPHA Gregory, 1910 \\ TALPIDAE Fischer, 1814 \\ UROPSILINAE Dobson, 1883 \\ Desmanella Engesser, 1972 \\ Desmanella sp.}

\section{Fig. 3.1-3.7}

Material: Cañ 10: 1 P4 sin. $(1.51 \times 1.38), 1$ P4 dext. (1.53 × 1.31), $1 \mathrm{M} 1$ sin. $(2.13 \times 1.79), 1 \mathrm{M} 2$ sin. damaged, $1 \mathrm{M} 2$ dext damaged, 2 M3 dext. $(1.02 \times 1.48 ; 1.05 \times 1.49)$, $4 \mathrm{M} 3 \sin .(1.10 \times 1.59 ; 1.02 \times 1.43 ; 1.06 \times 1.46 ;-\times-), 1 \mathrm{~m} 1$ $\sin$. $(1.61 \times 1.04 \times 1.19), 1 \mathrm{~m} 2$ dext. $(1.79 \times 1.17 \times 1.19), 1$ $\mathrm{m} 3 \sin .(1.30 \times 0.89 \times 0.64)$.

\section{Description:}

P4: The P4 comprises a large paracone and a lingual flange carrying a conical, well-developed protocone. The posterocrista of the paracone is sharp. It curves at its end, continuing in the posterior cingulum. An anterior flange in front of the paracone carries a very low, ridge-shaped parastyle. The premolar is almost completely surrounded by a cingulum, with only short interruptions on the anterolingual side of the protocone and the labial side of the paracone.

M1: The occlusal outline is remarkably quadrangular for a talpid M1. The posterior arm of the paracone and the anterior arm of the metacone are about the same length; the mestostyle is undivided. The posterior arm of the metacone is only somewhat longer than its anterior arm. The parastyle is connected to the protoconule, thus forming one continuous ridge with the lingual complex. This ridge continues over the hypocone, finally connecting to the posterior cingulum. The lingual wall of the complex shows only slight concavities between the protocone and protoconule and hypocone, respectively. On the labial side, the concavities are slightly more pronounced, particularly between protocone and protoconule. There are three transverse connections between the parastyle-lingual complex and the two labial cusps: one between parastyle and paracone, one connecting the protoconule to the base of the paracone and a third connecting the hypocone to the anterolingual side of the metacone. The M1 is bordered by a well-developed posterior cingulum.

M2: Both preserved M2 are damaged, one lacking the anterior arm of the paracone, the other missing the posterior arm of the metacone. The molar is only somewhat wider than long. The labial cusps are about the same size, and occupy about two-third of the molar. In the lingual complex, the protocone protrudes lingually. The protoconule is closer to the protocone than the hypocone, making the molar slightly asymmetrical. One specimen has concavities between protocone and proconule on both sides of the connecting ridge, in the other such an indentation is present on the lingual side only. Between protocone and hypocone there is only a very slight lingual concavity. The ridge connecting the cusps of the lingual complex continues both towards the front and toward the back over the anterior and posterior cingulum, respectively.

M3: The outline of the occlusal surface is semi-circular. The anterior arm of the paracone is around 50\% longer than the posterior arm. The mesostyle is undivided. The lingual part consists mainly of the protocone. A protoconule is indicated in only part of the specimens. The hypocone appears as a knob, directly lingual to the base of the metacone. The well-developed anterior cingulum is continuous with the anterior arm of the protocone. Usually this cingulum stops just short of the anterolabial corner of the M3, but reaches it in one specimen.

$\mathrm{m} 1$ : The trigonid is clearly narrower and shorter than the talonid. The blade-like paraconid is low. The oblique cristid runs in the direction of the metaconid, but ends against the posterior wall of the trigonid just short of that cusp. A short but high metacristid is fused with the metaconid. The entocristid is strongly developed. Behind the entoconid lies a sharply protruding entostylid. There is no parastylid. There is a nearly continuous cingulum along the anterior, labial and posterior sides, with only a short interruption near the base of the hypoconid. Lingually, there is a patch of well-developed cingulum near the opening of the trigonid basin.

$\mathrm{m} 2$ : The talonid and trigonid are of similar length and width. The paralophid is considerably longer and somewhat higher than in the $\mathrm{m} 1$. The oblique cristid is straight and ends close to the metaconid. Like in the $\mathrm{m} 1$, the metacristid is fused with the metaconid. There is a strong, slightly protruding entostylid behind the entoconid. The parastylid is formed by a knob on the anterior cingulum. The molar is nearly surrounded by a well-developed cingulum, which is only lacking along the lingual side of the talonid.

m3: The talonid is clearly narrower and somewhat shorter than the trigonid. The oblique cristid ends low against the base of the metaconid. There is a welldeveloped anterior cingulum, which tapers out along the labial side, ending near the base of the hypoconid.

\section{Remarks:}

The presence of the genus Desmanella in the area had already been noted by De Jong (1988) who described the locality of Pedregueras 2A (Biozone I) as Desmanella crusafonti. Already in his discussion, he indicated the 


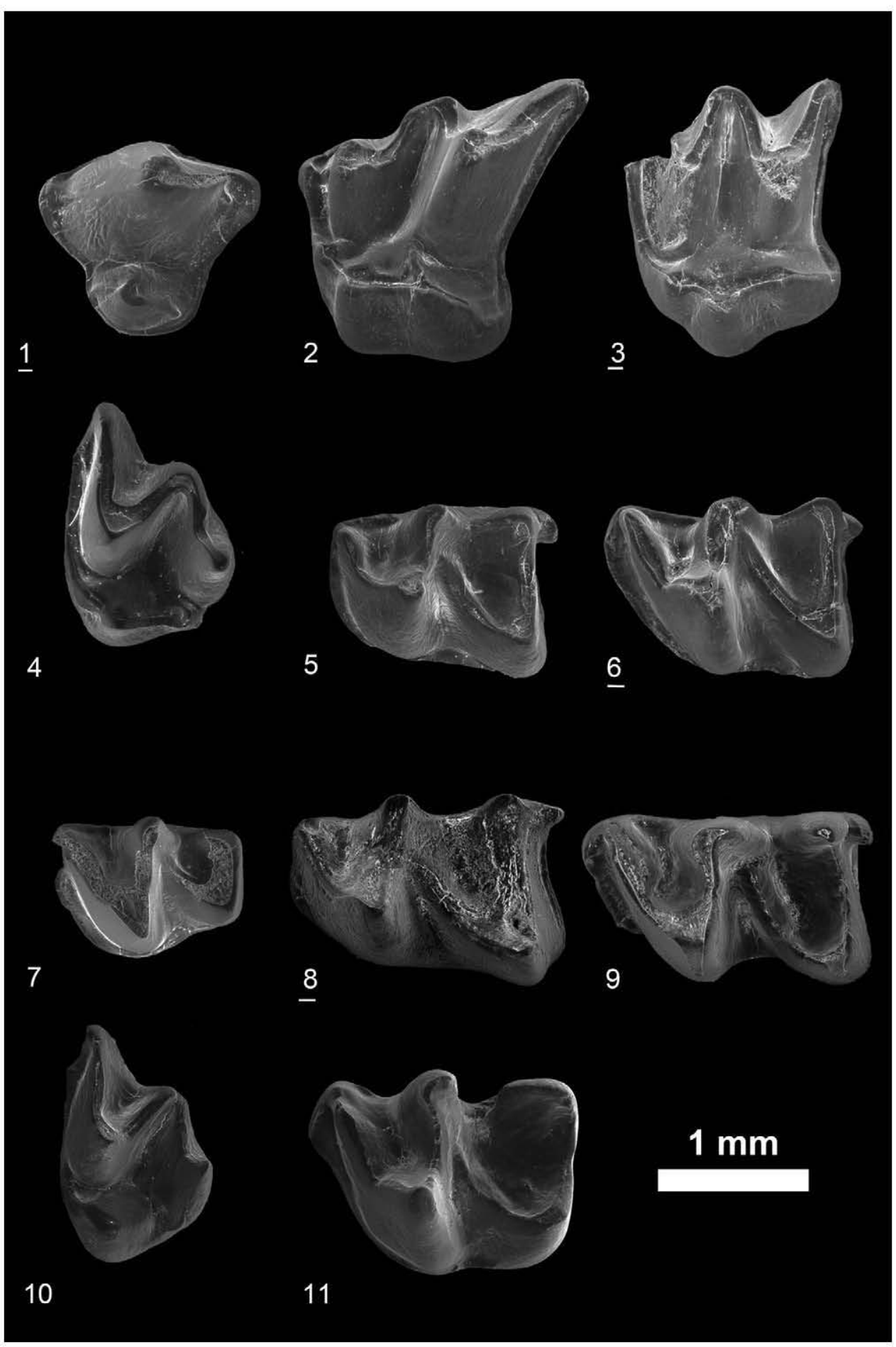

Fig. 3. Talpidae from the Cañada section. Desmanella sp. from Cañada 10: 1. P4dext. (CAÑ 10-26); 2. M1 sin. (CAÑ 10-27); 3. M2 dext. (CAÑ 10-28); 4. M3 sin. (CAÑ 10-30); 5. $\mathrm{m} 1 \mathrm{sin}$. (CAN 10-20); 6. $\mathrm{m} 2$ dext. (CAN 10-25) $7 \mathrm{~m} 3 \mathrm{sin}$. (CAN 10-43). Desmanella cf. crusafonti from Cañada 12: 8. m1 dext. (CAÑ 12-94); 9 . m2 sin. (CAÑ 12-91); 10. M3 sin. (CAÑ 12-93). Archaeodesmana sp. from Cañada 12: 11. m3 sin. (CAÑ 12-88.)

Fig. 3. Talpidae de la section de la Cañada. Desmanella sp. de Cañada $10: 1$. P4 dext. (CAÑ 10-26); 2. M1 sin. (CAÑ 10-27); 3. M2 dext. (CAÑ $10-28$ ); 4. M3 sin. (CAÑ 10-30); 5. m1 sin. (CAÑ 10-20); 6. $\mathrm{m} 2$ dext. (CAÑ 10-25), $7 \mathrm{~m} 3 \mathrm{sin}$. (CAÑ 10-43). Desmanella cf. crusafonti de Cañada $12: 8$. m1 dext. (CAÑ 12-94); 9 . m2 sin. (CAÑ 12-91); 10. M3 sin. (CAÑ 12-93). Archaeodesmana sp. de Cañada 12: 11. m3 sin. (CAÑ 12-88). 
differences between the early Vallesian form and the material from the type locality, Concud 3 . These dissimilarities are such, that in our present understanding, the Desmanella from the early Vallesian can in fact not be included in D.crusafonti. These differences are now confirmed in the material from Cañada 10 . The cingulums are much better developed in the Cañada assemblage than in the Turolian species, the protocone extends lingually, and the demarcation between the protocone and the lingual cusps is less pronounced. Clearly, the early Vallesian material represents a separate species. However, since our good colleague Jan van Dam has told us he intends to publish this early Vallesian Desmanella in the near future, it would be inappropriate to assign a specific name to it here.

\section{Desmanella cf. crusafonti Rümke, 1974}

\section{Fig. $3.8-3.10$}

Material: Cañ $12: 1 \mathrm{M} 3 \sin .(0.96 \times 1.54), 1 \mathrm{~m} 1$ dext. $(1.65 \times 0.92 \times 1.11), 1 \mathrm{~m} 2 \sin .(1.81 \times 1.09 \times 1.15)$.

\section{Description:}

M3: The outline of the occlusal surface is semi-circular; the molar is clearly wider than long. In our unworn specimen, there is a slight division of the mesostyle. The lingual part of the M3 is formed by the protocone, which has a rounded posterior side. Its anterior arm is continuous with the anterior cingulum, which is very narrow and patchy. Near its ends, it widens, and forms a larger patch, which does, however, not reach the anterolabial side of the molar. A tiny bulge at the lingual base of the metacone may represent a remnant of the hypocone.

$\mathrm{m} 1$ : The only available specimen is somewhat corroded, obliterating part of the features. The trigonid is narrower and somewhat shorter than the talonid. The oblique cristid ends against the posterior wall of the trigonid at about two-third its length. Due to the corrosion, the presence of a metacristid cannot be ascertained. An entocristid is present, as well as a protruding entostylid. Remnants of a cingulum are found on the posterior and anterior sides, but corrosion prevents a good assessment of cingular development.

$\mathrm{m} 2$ : The talonid is somewhat wider than the trigonid. The metaconid is fused with a very well-developed metacristid. The oblique cristid ends against the metaconid/metacristid complex. The entocristid is well developed and fused with the entoconid. Both metacristid and entocristid are high, but they are separated by a deep notch, creating a narrow opening for the talonid basin. There is a strong parastylid, situated on the wide anterior cingulum in front of the paraconid. In contrast, the entostylid is small and the posterior cingulum is very narrow. Due to slight damage at the lingual base of the only specimen, the cingular development on this side cannot be assessed.

\section{Remarks:}

Somewhat ironically, directly after having refuted the evidence for the presence of $D$. crusafonti in the area as given by De Jong (1988), we assign material from the Cañada section to that very species. However, these finds are from the Turolian assemblage of Cañada 12 . Unfortunately, the M1 and M2, which are the more characteristic elements, have not been found. Nevertheless, the lower molars show a cingular development similar to the Turolian species. The M3 seems to be a bit aberrant, as Rümke (1974) describes the hypocone as being present. However, one of the M3 she figures (pl. 2, fig. 10) has a morphology that is very close to that of the Cañada specimen. López-Guerrero et al. (2011) correlated Cañada 12 to Biozone L of Van Dam et al. (2001). As this is also the zone in which Concud 3, the type locality of D. crusafonti, is placed, the occurrence of this Desmanella also fits from a stratigraphic point of view.

DESMANINAE Thomas, 1912

Archaeodesmana Topachevski and Pashkov, 1983

Archaeodesmana sp.

Figs. 3.11 and 4.1

Material: Cañ 12: 1 damaged $m 1$ dext., $m 3$ sin. $(1.89 \times 1.30 \times 1.19)$.

\section{Description:}

$\mathrm{m} 1$ : The specimen is damaged at the posterior side, lacking part of the hypoconid and entoconid. As far as can be judged, the trigonid only seems to be somewhat narrower than the talonid. The cusps of the trigonid are sturdily built. The protoconid has a triangular cross-section, the metaconid is conical and the somewhat lower paraconid takes the aspect of a thick blade. The connections between the protoconid and the other two cusps are low. The oblique cristid just reaches the labial side of the metaconid. There is no metacristid, but well-developed entocristid borders part of the talonid basin. The anterior cingulum is well developed. Labially, part of a thick cingulum bordering the re-entrant valley has been preserved. On the lingual side, there is a strong patch of cingulum below the opening of the trigonid valley.

$m 3$ : The $m 3$ is unworn. The outline of the occlusal surface is subrectangular, the talonid being only slightly narrower than the trigonid. The paralophid is low, ending in a blade-like paraconid. The oblique cristid is slightly curved; it ends just lingual to the middle of the protolophid. The entocristid is very well developed and merged with the entoconid. There is a very short metacristid. A very thin cingulum starts at the base of the hypoconid and extends towards the paraconid. There, it becomes very wide, forming a slightly protruding parastylid.

\section{Remarks:}

Initially, both elements of the Cañada desman were wrongly identified. The $\mathrm{m} 1$ was listed as cf. Dinosorex and the $\mathrm{m} 3$ as Talpa sp. in López-Guerrero et al. (2011). In fact, it is thanks to the keen attention of the reviewers that we emended these identifications. The problem in identifying the $\mathrm{m} 1$, apart from its damage, lay in the rather atypical metaconid, which is far more conical than generally found in desmans. This resulted in a more lingual termination of the oblique cristid. Though unusual, such a configuration resembles the $\mathrm{m} 1$ of Dibolia (=Archaeodesmana) luteyni figured by Rümke (1985, fig. 


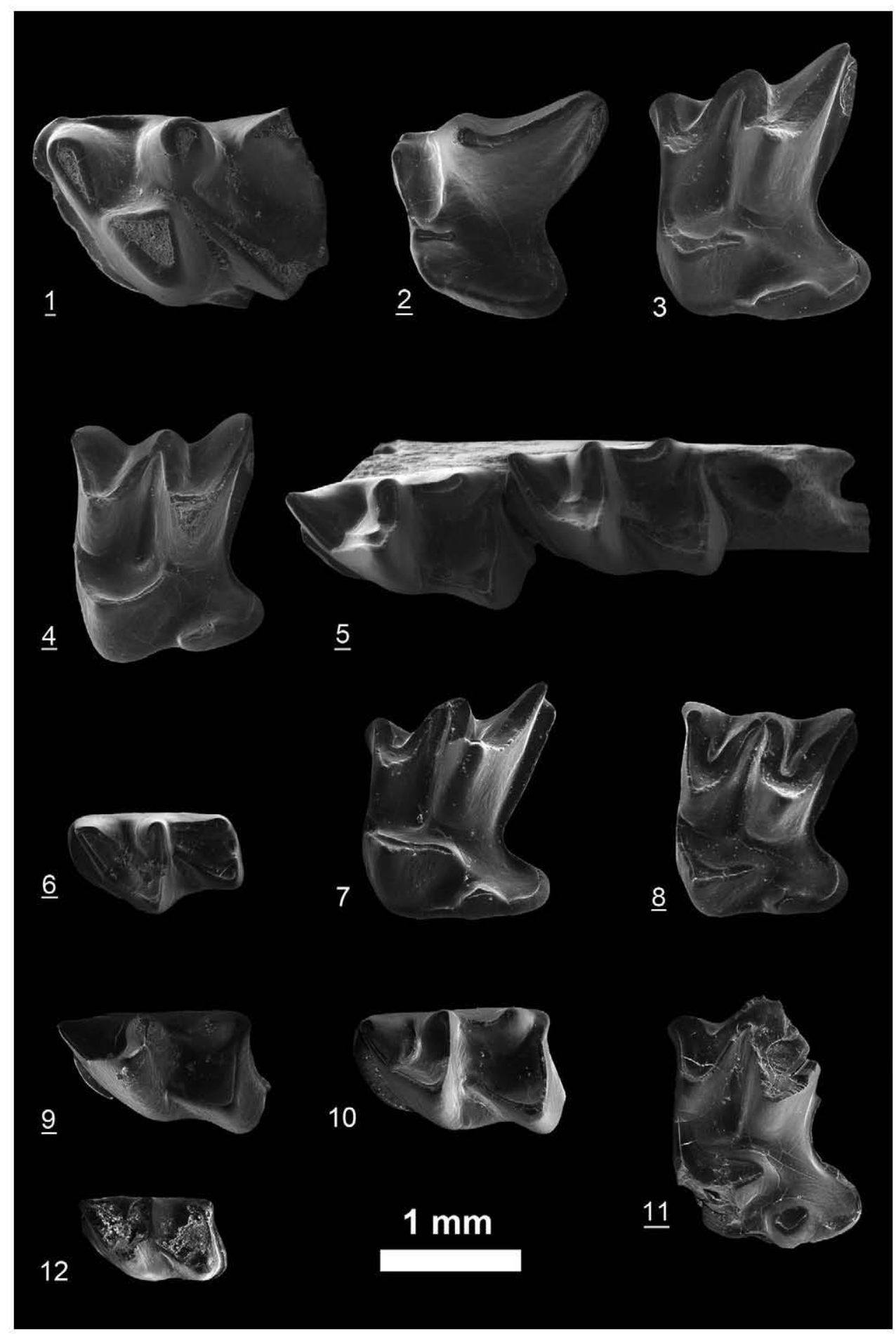

Fig. 4. Talpidae and Soricidae from the Cañada section. Archaeodesmana from Cañada 12: 1. m1 dext. fragm. (CAÑ 12-87). Miosorex sp. from Cañada 8: 2. P4 dext (CAN 8-107), 3. M1 sin. (CAN 8-101); 4. M2 dext (CAÑ 8-109); 5. mandible with m1, m2 dext (CAN 8-106), 6. m3 dext. (CAÑ 8-105). Soricidae indet from Cañada 8: 7. M1 sin. (CAÑ 8-108); 8. M2 dext. (CAÑ 8-124); 9. m1 dext. (CAÑ 8-103); 10. m2 sin. (CAN 8-104). Turiasorex pierremeini from Cañada 10: 11. M1 dext. (CAÑ 10-36). Paenelimnoecus sp. from Cañada 12: 12. $\mathrm{m} 2$ sin. (CAÑ 12-86.)

Fig. 4. Talpidae et Soricidae de la section de la Cañada. Archaeodesmana de Cañada $12: 1$. $m 1$ dext. fragm. (CAÑ $12-87$ ). Miosorex sp. de Cañada $8: 2$. P4 dext (CAÑ 8-107), 3. M1 sin. (CAÑ 8-101); 4. M2 dext. (CAÑ 8-109); 5. mandibule avec m1, m2 dext (CAÑ 8-106), 6. m3 dext. (CAÑ 8-105). Soricidae indet. de Cañada 8: 7. M1 sin. (CAN 8-108); 8. M2 dext. (CAÑ 8-124); 9. m1 dext (CAÑ 8-103); 10. m2 sin. (CAN 8-104). Turiasorex pierremeini de Cañada 10 : 11. M1 dext. (CAÑ 10-36). Paenelimnoecus sp. de Cañada $12: 12$. m2 sin. (CAÑ 12-86). 
62.1). We misidentified the $\mathrm{m} 3$ mostly because we considered the crown high, when in fact it is merely remarkably unworn. In this specimen, the oblique cristid also does not reach as far lingually as is common in desmans, but still resembles the situation in the specimen of Dibolia (=Archaeodesmana) major in Rümke (1985, fig. 16.1). In size, the specimen also falls within the variation of the latter species. Notably, Archaeodesmana luteyni and A. major have both been described from the Turolian of east Central Spain.

The first record of Desmaninae in the neighbouring Teruel Basin is that from the Turolian locality of Vivero de Pinos (Biozone K, Van Dam et al., 2001). From then on, they are a very common element in the insectivore faunas of the Teruel Basin, and their presence in Cañada 12 , although the first record for the Calatayud-Montalbán Basin, is therefore no surprise.

\section{SORICIDAE Fischer 1814 \\ CROCIDOSORICINAE Reumer, 1987 \\ Miosorex Kretzoi, 1959 \\ Miosorex sp.}

\section{Fig. 4.2-4.6}

Material: Cañ 8: P4 dext. $(1.77 \times 1.50), 4$ M1 sin. $(1.62 \times 2.04 ; 1.56 \times 1.99 ; 1.65 \times 1.96 ; 1.64 \times 2.01), 3 \mathrm{M} 1$ dext. $(1.56 \times 2.06 ; 1.57 \times 2.04 ; 1.52 \times 2.07), 1 \mathrm{M} 2$ sin. $(1.42 \times 1.82), 2$ M2 dext. $(1.41 \times 1.83 ; 1.44 \times 1.89), 1$ mandible fragment with $\mathrm{m} 1, \mathrm{~m} 2 \mathrm{sin} .(1.67 \times 0.99 \times 1.09$; $1.64 \times 1.04 \times 1.08), 1$ mandible fragment with $\mathrm{m} 1$ dext. $(1.66 \times 0.98 \times 1.11), 1$ mandible fragment with $\mathrm{m} 2$ dext. and trigonid of $\mathrm{m} 3(1.61 \times 1.03 \times 1.06), 1 \mathrm{~m} 2 \mathrm{sin}$. $(1.71 \times 0.92 \times 0.95), 1 \mathrm{~m} 3$ dext. $(1.31 \times 0.70 \times 0.54)$; Cañ 9: 1 damaged $\mathrm{m} 2$ dext, 1 mandible with $\mathrm{m} 3$ dext. $(1.26 \times 0.76 \times 0.59)$.

\section{Description:}

P4: The P4 shows a moderate posterior emargination. The paracone is high and sharp. The parastyle, positioned directly anterior to the base of the paracone, is conical and well developed. The protocone is double-tipped, giving its cross-section the aspect of the number 8 . Protocone and parastyle are connected to one another by a low ridge. Low against the anterolingual flank of the M1, a well-defined ridge starts, and borders the premolars, reaching up to the anterolabial corner of the P4.

M1: The molar is somewhat wider than long. The posterior emargination is moderate. The mesostyle is undivided. The anterior arm of the protocone ends high against the lingual side of the paracone; the posterior arm ends freely between the base of the metacone and the hypocone. In one specimen, there is a low transverse connection between this arm and the metacone. The hypocone is well developed, forming a thick ridge.

M2: The M2 is somewhat wider than long. The posterior emargination is moderate. The paracone is slightly smaller than the metacone. The anterior arm of the paracone and posterior arm of the metacone extend further labially than the mesostyle, which is undivided. The anterior arm of the protocone ends against the base of the paracone; the posterior arm connects low to the base of the metacone. The ridge-shaped hypocone is well developed.

$\mathrm{m} 1$ : The trigonid is clearly narrower and longer than the talonid. The paralophid is long, making the trigonid basin open. The short oblique cristid ends against the base of the protoconid. The hypolophid lies against the posterolabial flank of the entoconid. The cingulum is best developed on the anterior side. On the labial side it is narrow, but continuous. The posterior cingulum is only somewhat wider than the labial one.

$\mathrm{m} 2$ : The trigonid is only somewhat narrower than the talonid, and of about the same length. The protolophid and paralophid stand much closer together than in the $\mathrm{m} 1$. The oblique cristid ends somewhat more to the lingual side, but still closer to the base of the protoconid than to the metaconid. Other than in the $\mathrm{m} 1$, the hypolophid is slightly separated from the entoconid. The cingulums are developed as in the first molar, but the anterior cingulum extends a bit more lingually.

$m 3$ : The trigonid of the $m 3$ is a smaller version of that of the $\mathrm{m} 2$. Although the talonid is narrower than the trigonid, it is not strongly reduced. Entoconid and hypoconid are still discernable, as is a shallow talonid basin. The oblique cristid ends close to the metaconid. The narrow labial cingulum is continuous with the much better developed anterior cingulum.

\section{Remarks:}

The genus Miosorex is quite a common element in Aragonian and Vallesian insectivore faunas. De Jong (1988) recorded Miosorex grivensis from all the late Aragonian and early Vallesian localities in his study, and Van Dam et al. (2001) also found Miosorex sp. in most of their Vallesian faunas, the youngest occurrence in the Teruel basin being in Puente Minero 10 (Biozone J2). Furthermore, Furió et al. (2011b) indicated that Miosorex was already present in Spanish localities from the early Aragonian onwards, and it represents a common element in the Aragonian type section (Van der Meulen et al., 2012). Although the material from Cañada 8 doubtlessly belongs to the same species as De Jong's M. grivensis, we deem it prudent to leave the classification at Miosorex sp., until such time that the Iberian Miosorex material can be revised in detail, including a comparison with $M$. grivensis from its type locality. Unfortunately, the identification of $M$. grivensis was still listed for Cañada 8 in López-Guerrero et al. (2011), although the more prudent identification was already used for the captions. A closer look at the shrew remains from Cañada 9 convinced us that these too can be classified as Miosorex sp., whereas we still had listed them as Soricidae indet. in Lôpez-Guerrero et al. (2011).

\author{
Turiasorex Van Dam, Van den Hoek Ostende and Reumer, \\ 2011 \\ Turiasorex pierremeini Van Dam, Van den Hoek Ostende \\ and Reumer, 2011
}

Fig. 4.11

Material: Cañ 10: 1 damaged M1 sin. 


\section{Description:}

M1: The only specimen is damaged, lacking the lingual part of the protocone and the metastyle. Despite this, it is clear that the molar is short relative to its width. The paracone is much smaller than the metacone. The hypocone is conical, and lies posterolingually to the posterior arm of the protocone.

\section{Remarks:}

The genus Turiasorex and its type species T. pierremeini were recently described by Van Dam et al. (2011). The short upper M1 and M2 gives these elements a typically slender occlusal outline. Therefore, in spite of being badly damaged, the Cañada 10 specimen is readily identifiable as Turiasorex.

The presence of Turiasorex in the Cañada section is hardly surprising. It is known from several localities in the area, both older and younger than Vallesian assemblages of the section (e.g., from Borjas, Solera, Pedregueras 2A). The known stratigraphic range of the genus encompasses Biozones G2 through I.

Soricidae gen. et sp. indet.

Fig. 4.7-4.10.

Material: Cañ $8: 1$ M1 sin. $(1.47 \times 1.81), 1$ M2 sin. $(1.36 \times 1.63), 1 \mathrm{M} 2$ dext. $(1.38 \times 1.61), 1 \mathrm{~m} 1$ dext. $(1.51 \times 0.86 \times 0.99), 1$ mandible fragment with slightly damaged $m 2$ dext.

\section{Description:}

M1: The outline of the occlusal surface is quadrangular, except that the metastyle protrudes. The posterior emargination is moderate. In our hardly worn specimen, there is still a faint division of the mesostyle. The anterior arm of the protocone ends against the base of the paracone; the posterior arm ends freely off the base of the metacone. The hypocone is well developed, bud-like.

M2: The second molar is only somewhat wider than long. The paracone is slightly smaller than the metacone. There is a faint division of the mesostyle, but this is likely to disappear even at moderate stages of wear. The anterior arm of the protocone ends against the base of the paracone; the posterior arm ends freely between the base of the metacone and the hypocone. The latter is bud-like and well developed.

$\mathrm{m} 1$ : The trigonid is somewhat narrower and shorter than the talonid. The paralophid is long and extends forward, creating an open trigonid basin. The protoconid and metaconid are positioned closely together. The oblique cristid ends just lingually of the base of the protoconid. The hypolophid is curved backwards, runs behind the entoconid and is separated from it by a narrow valley. There are well-developed cingulums on the anterior and posterolabial sides of the $\mathrm{m} 1$; the labial cingulum is narrow but continuous.

$\mathrm{m} 2$ : The only $\mathrm{m} 2$ available is damaged on the labial side. The trigonid is shorter than the talonid. Though the paralophid is not directed forward as in the $\mathrm{m} 1$, the trigonid basin is still relatively open. The oblique cristid ends a bit more lingually than in the $\mathrm{m} 1$. As in the first molar, the hypolophid is separated from the entoconid by a narrow valley. The anterior cingulum is very strong, particularly in its lingual part. Due to the damage, the other cingular development cannot be assessed.

\section{Remarks:}

The second shrew species in the Cañada 8 assemblage shows strong similarities with the Miosorex from the same locality. It differs in a more slender aspect of all the cusps, and smaller dimensions, particularly in the width of the molars. Overall, it displays a very basic soricid dental morphology. In the absence of a $\mathrm{p} 4$, it is not possible to determine to which subfamily it should be attributed.

\section{ALLOSORICINAE Fejfar, 1966 \\ Paenelimnoecus Baudelot, 1972 \\ Paenelimnoecus sp.}

Fig. 4.12

Material: Cañ $12: 1 \mathrm{~m} 2 \sin .(1.14 \times 0.68 \times 0.71)$.

\section{Description:}

The outline of the occlusal surface is subrectangular; trigonid and talonid are of similar length and width. Protolophid and paralophid stand at a relatively large angle, creating a wide trigonid basin. The oblique cristid ends against the middle of the protolophid. The entoconid is strongly reduced. The cingulum is thin on the labial and posterior sides, somewhat better developed on the anterior side.

\section{Remarks:}

Like Miosorex, Paenelimnoecus is a common taxon in the Central Spanish basins. It was already present in both the Daroca-Villafeliche and the Calamocha area of the Calatayud-Montalbán Basin during the Aragonian (Van den Hoek Ostende et al.,2009a), and was regularly found in both Vallesian and Turolian faunas from the Teruel Basin (Van Dam et al., 2001). As Van den Hoek Ostende et al. (2009a) pointed out, it may in fact be regularly overlooked because of its small size, particularly when an $0.7 \mathrm{~mm}$ mesh size was used during screen-washing. Unfortunately, the single specimen from Cañada 12 had a small mishap after being photographed, and is now severely damaged.

The subfamily to which Paenelimnoecus should be assigned is still fiercely debated. As a single $\mathrm{m} 2$ has little to add to this discussion, we here follow the classification used in Van den Hoek Ostende et al. (2009a).

\section{Discussion}

Three levels from the Cañada section have yielded relevant insectivore assemblages. These are Cañ 8, assigned to Biozone H by López-Guerrero et al. (2011), Cañ 10 , which was tentatively assigned to the uppermost part of Biozone H, and the Turolian level of Cañ 12. From these, Cañ 8 has the highest number of insectivore fossils. In fact, it is exceptional that, based on the number of first and second molars, it contains more insectivores than rodents (22 versus 19 ). The proportion of insectivores is also notably high in Cañ 10 (eight versus 19), whereas the youngest level shows a more usual proportion (five versus 37). De Jong (1988) had already noted that proportion of insectivores in the Vallesian of the Daroca area is higher than that from the Aragonian. The high proportion of 
insectivores in the Vallesian assemblages confirms the return to more humid conditions in the area, as was already indicated by the presence of beavers in nearly all of the Cañada assemblages (López-Guerrero et al., 2007, 2011). As the first Castoridae are already present in Toril 3A, the change to more humid conditions seems to have started already in the Late Aragonian. A more detailed palaeoecological analysis of the sections needs to be made in combination with all of the rodents, and is outside the scope of this article.

There are marked differences in the composition of the insectivore assemblages of Cañada 8 and 10. The latter only contains one molar of a shrew, and for that, one that has not been found in Cañada 8, viz. Turiasorex. The Cañada 8 assemblage, on the other hand, is dominated by shrews, and lacks talpids, represented in Cañada 10 by Desmanella. The two assemblages do share Parasorex, but then again, this galericine is found in almost all Iberian Late Miocene faunas. This change in insectivores is mirrored by a change in the rodent fauna, with, for instance, the glirid Ramys appearing for the first time in Cañ 10.

The near absence of Soricidae in Cañada 10 is considered an artefact of the sample size. As noted earlier, Miosorex is a very common element in the Aragonian and Vallesian faunas of the area. It is known to co-occur with Desmanella in Pedregueras 2A (De Jong, 1988) as well as in a series of Vallesian localities in the Teruel Basin (Van Dam et al., 2001).

The occurrence of Desmanella in Cañada 10 does seem to represent a new immigration in the basin. This mole has not been encountered in the fauna from Biozone $\mathrm{H}$, but had already been noted in the Biozone I localities of Pedregueras 2A (De Jong, 1988). The oldest known occurrence in the Teruel Basin is in Peralejos A (Biozone J2, Van Dam et al., 2001). The migration of Desmanella marks the re-appearance of talpids in the basin after a prolonged absence, indicating a return to more humid conditions (García-Alix et al., 2011). The genus Desmanodon was common in the area in the late Early and early Middle Miocene (Van den Hoek Ostende, 1997), but extirpated in Biozone $\mathrm{Db}$ (Van der Meulen et al., 2012).

The small assemblage of Cañada 12 fits well with the insectivore assemblages from Biozone $\mathrm{L}$ in the Teruel Basin (Van Dam et al., 2001), in which Archaeodesmana, Paenelimnoecus, Desmanella and Parasorex are common elements. Our tentative identification of Postpalerinaceus would slightly enlarge the known range of that genus.

\section{Conclusions}

Though the insectivore assemblages from the Cañada section are small, they provide some additional information in the history of the group in the Spanish Vallesian. De Jong's (1988) conclusion that the proportion of insectivores in the overall micromammal fauna is higher in the Vallesian than in the Aragonian is confirmed, with the insectivores even outnumbering the rodents in the assemblage of Cañada 8. This, in combination with the relatively large number of taxa found, shows that conditions were favourable for insectivores in the Spanish inland basins during the Vallesian. The re-appearance of Talpidae in the Daroca area (represented by Desmanella) at the end of Biozone $\mathrm{H}$ is in line with this amelioration of the conditions. Cañada 12 (Biozone L) shows an insectivore assemblage which is very similar to the ones found in the Teruel basin.

\section{Acknowledgements}

It is over ten years now that a team consisting of most of the authors sampled the Cañada section. Our friend and colleague Albert van der Meulen was still in the field with us during that campaign, and we fondly remember his inspiring presence. The former staff of hotel Legido (Daroca) provided a home away from home for so many years, for which we are grateful. The SEM photographs were made by Alberto J.García (MNCN-CSIC, Madrid), and Rutger van den Hoek Ostende assisted in making the figures. Leslie Rault translated the abstract into French, which was further improved by Jêrôme Prieto. We are most grateful for the work done by the reviewers Marc Furio and Jérôme Prieto, who, apart from correcting our misidentification of the desman, also had a score of other useful suggestions. Kevin Padian suggested a number of linguistic corrections. We acknowledge financial support by the Spanish MICINN projects CGL2004-02094/BTE, CGL200765208, CGL2008-00325/BTE, CGL2008-04200/BTE, CGL2011-2887 (MICINN/MINECO) and Research Group BSCH-UCM 910607. I.G.P.acknowledges a JAE-Doc contract (CSIC program "Junta para la Ampliaciốn de Estudios"), co-funded by the European Social Fund, and P.L.G.acknowledges a UCM Predoctoral contract. L.H.O. was supported by the EC-funded IHP Programme Biod-IBERIA.

\section{References}

Adrover, R., 1986. Nuevas faunas de roedores del Mio-Plioceno continental de la región de Teruel (España). Interés bioestratigráfico y paleoecológico. Ins tituto de Estudios Turolenses, Teruel, 423p.

Álvarez-Sierra, M.Â., Calvo, J.P., Morales, J., Alonso-Zarza, M.A., Azanza, B., García Paredes, I., Hernández Fernández, M., van der Meulen,A.J.,Peláez-Campomanes,P.,Quiralte,V.,Salesa, M.J., Sánchez, I.M., Soria, D., 2003. El tránsito Aragoniense-Vallesiense en el área de Daroca-Nombrevilla (Zaragoza, Es paña). Coloquios de Paleontol. Vol. Extraordinario 1,25-33.

De Jong, F., 1988. Insectivora from the upper Aragonian and the lower Vallesian of the Daroca-Villafeliche area in the CalatayudTeruel Basin (Spain). In: Freudenthal, M. (Ed.), Biostratigraphy and paleoecology of the Neogene micromammalian faunas from the Calatayud-Teruel Basin (Spain). Scripta Geol. Spec. Issue 1, pp. $253-286$.

Furió, M., Casanovas-Vilar, I., Moyà-Solà, S., Köhler, M., Galindo, J., Alba, D.M., 2011a. Insectivores (Eulipotyphla; Mammalia) from the Middle Miocene of Baranc de Can Vila 1 (Vallès-Penedès Basin, Catalonia, Spain). Geobios 44, 199-213.

Furió, M., Casanovas-Vilar, I., Van den Hoek Ostende, LW., 2011b. Predictable structure of Miocene insectivore (Lipotyphla) faunas in Western Europe along a latitudinal gradient. Palaeogeogr., Palaeoclimat., Palaeoecol. 304, 219-229.

García-Alix, A., Furió, M., Minwer-Barakat, R., Martín-Suárez, E., Freudenthal, M., 2011. Environmental control on the biogeographical distribution of Desmanella (Soricomorpha, Mammalia) in the Miocene of the Iberian Peninsula. Palaeontology 54 (4), 753-762. 
López-Guerrero, P., Oliver Pérez, A., Âlvarez-Sierra, M.Á., García-Paredes, I., Peláez-Campomanes, P., 2007. El registro de los Castoridae (Rodentia, Mammalia) del Aragoniense y Vallesiense (Mioceno Medio y Superior) de las cuencas centrales españolas. In: Braga, J.C., Checa, A., Compani, M. (Eds.), XXIII Jornadas de la Sociedad Es pañola de Paleontología. Libro de resûmenes. Instituto Geológico y Minero de España \& Universidad de Granada, Granada, pp. 118-119.

López-Guerrero, P., García-Paredes, I., Van den Hoek Ostende, L.W., Van Dam, J.A., Álvarez-Sierra, M.Á., Hernández-Ballarín, V., Van der Meulen, A.J., Oliver, A., Peláez-Campomanes, P., 2011. Cañada: a new micromammal succession from the Lower Vallesian and Turolian of the Daroca area (Calatayud-Montalbán basin, Spain). Estud. Geol. 67, 443-453.

López-Guerrero, P., García-Paredes, I., Álvarez-Sierra, M.A., submitted Revision of Cricetodon soriae (Rodentia, Mammalia), new data from the middle Aragonian (middle Miocene) of the Calatayud-Daroca basin (Zaragoza, Spain). J. Vert Paleontol.

Mein, P., 1999. The small mammal Vallesian and Turolian succession of France. In: Agustí, J., Rook, L., Andrews, P. (Eds.), Evolution of Neogene Terrestrial Ecosystems in Europe. Cambridge University Press, Cambridge, pp. 140-164.

Prieto, J., Van den Hoek Ostende, L.W., Böhme, M., 2011. Reappearance of Galerix (Erinaceomorpha, Mammalia) at the Middle to Late Miocene transition in South Germany: biostratigraphic and paleoecologic implications. Contrib. Zool. 80, 179-189.

Prieto, J., Van den Hoek Ostende, L.W., Hír, J., 2012. The Middle Miocene insectivores from Sámsonháza 3 (Hungary, Nógrád County): Biostratigraphical and environmental conditions near to the Middle Miocene Cooling. Bull. Geosci. 87 (2), 227-240.

Reumer, J.W.F., 1984. Ruscinian and early Pleistocene Soricidae (Insectivora, Mammalia) from Tegelen (The Netherlands) and Hungary. Scripta Geol. 73, 1-173.

Rümke, C.G., 1974. A new Desmanella species (Talpidae, Insectivora) from the Turolian of Concud and Los Mansuetos (Province of Teruel, Spain). Proc. K. Ned. Akad. Wetensch. B 77, 359-374.
Rümke, C.G., 1985. A review of fossil and recent Desmaninae (Talpidae, Insectivora). Utrecht Micropaleontol. Bull. Spec. Publ. 4, $1-241$.

Van Dam, J.A., Alcalá, L., Alonso Zarza, A., Calvo, J.P., Garcés, M., Krijgsman, W., 2001. The upper Miocene mammal record from the TeruelAlfambra region (Spain). The MN system and continental stage/age concepts discussed. J. Vert. Paleontol. 21, 367-385.

Van Dam, J.A., Van den Hoek Ostende, L.W., Reumer, J.W.F., 2011. A new short-snouted shrew from the Miocene of Spain. Geobios 44, 299-307.

Van den Hoek Ostende, L.W., 1997. Insectivore faunas from the Lower Miocene of Anatolia. Part 4: The genus Desmanodon (Talpidae) with the description of a new species from the Lower Miocene of Spain. Proc. K. Ned. Akad. Wetensch. 100, 27-65.

Van den Hoek Ostende, L.W., 2001. A revised generic classification of the Galericini (Insectivora, Mammalia) with some remarks on their palaeobiogeography and phylogeny. Geobios 34, 681-695.

Van den Hoek Ostende, L.W., Furió, M., 2005. Spain. In: Van den Hoek Ostende, L.W., Doukas, C.S., Reumer, J.W.F. (Eds.), The fossil record of the Eurasian Neogene insectivores (Erinaceomorpha, Soricomorpha, Mammalia). Part I. Scripta Geol. Spec. Issue 5, pp. $149-284$.

Van den Hoek Ostende, L.W., Furió, M., García-Paredes, I., 2009 a. New data on Paenelimnoecus from the middle Miocene of Spain support the shrew subfamily Allosoricinae. Acta Palaeontol. Pol. 54, 159-164.

Van den Hoek Ostende, L.W., Reumer, J.W.F., Doukas, C.S., 2009b. The nature of the fossil record of Neogene insectivores. Hellenic J. Geosci. $44,117-124$.

Van der Meulen, A.J., García-Paredes, I., Álvarez-Sierra, M.A., van den Hoek Ostende, L.W., Hordijk, K., Oliver, A., Peláez-Campomanes, P., 2012. Updated Aragonian biostratigraphy: small Mammal distribution and its implications for the Miocene European Chronology. Geol. Acta 10, $1-24$. 